\title{
PENGEMBANGAN DIRI MELALUI PEMBERDAYAAN DIRI
}

\author{
Oleh: Dian Miranda ${ }^{1}$
}

\begin{abstract}
Abstrak: Proses pemberdayaan biasanya dilaksanakan dengan dua cara, yaitu secara konseptual dan empirik. Pemberdayaan secara konseptual berarti peningkatan kemampuan menciptakan ide/gagasan atau secara lebih spesifik proses penyadaran diri (self awareness). Selanjutnya pemberdayaan empirik yang dilakukan individu untuk memperbaiki kehidupan dengan cara yang praktis. Langkahlangkah pemberdayaan diri meliputi (1) memeriksa keterbatasan diri, (2) memperluas batas, (3) membangun dialog batin yang positif, (4) mengupayakan dukungan.
\end{abstract}

\section{Kata Kunci: Pengembangan Diri, Pemberdayaan Diri,}

\section{A. PENDAHULUAN}

Milenium ketiga atau lebih dikenal sebagai era globalisasi memberikan banyak harapan, tetapi juga tantangan, ancaman, dan hambatan yang akan dialami setiap manusia, setiap bangsa, dan negara di muka bumi ini tanpa kecuali. Pesatnya perkembangan ilmu pengetahuan dan teknologi terutama perkembangan teknologi informasi (IT) menyebabkan dunia ini terasa semakin sempit sehingga membentuk suatu masyarakat dunia saling bergantung. Pada masa-masa yang akan datang batas negara yang satu dengan yang lainnya akan semakin kabur. Kehidupan politik, ekonomi, kebudayaan yang mengglobal tersebut tentunya memerlukan manusia yang mempunyai visi baru, mindset baru, dan dengan sendirinya membutuhkan kemampuan penyesuaian diri.

Kemajuan teknologi komunikasi telah membabat batas-batas isolasi manu-sia. Lahirlah apa yang disebut masyarakat terbuka (open society) di mana terjadi aliran bebas informasi, manusia perdagangan, dan bentuk-bentuk aktivitas kehidupan global lainnya yang menyatukan umat manusia. Dunia yang terbuka telah menciptakan apa yang disebut dunia tanpa batas. Manusia dewasa ini hidup di da-lam apa yang disebut global village) atau kampung global, sehingga terjadi per-singgungan antar kebudayaan, maka muncullah apa yang disebut kebudayaan global yang

\footnotetext{
${ }^{1}$ Dian Miranda adalah Dosen Jurusan Ilmu Pendidikan FKIP-UNTAN Pontianak.
} 
selain mempunyai nilai-nilai positif juga mengandung bahaya-bahaya laten.

Keadaan ini tentunya memerlukan manusia yang tidak terlempar dari akar kepribadian, kebudayaan dan falsafah hidupnya. Manusia Indonesia harus tetap be-rada dalam kehidupan yang harmonis berdasarkan akar budaya yang dapat menja-di pedoman kehidupannya. Dengan kata lain, manusia di dalam kehidupan modern perlu mempunyai identitas dan jati diri yang kuat. Sehingga kita dapat berperan dan ambil bagian di dalam proses globalisasi, tidak hanya sebagai penonton pasif dan terombangambing dalam tatanan nilai global yang terkadang kurang sesuai dengan nilai dan moral Bangsa Indonesia. Agar dapat berperan secara aktif dalam peru-bahan global, diperlukan kemampuan manajamen diri (self manajemen) secara se-imbang dalam aspek kognitif, sikap atau nilai-nilai untuk menghadapi tantangan, hambatan dan memanfaatkan peluang.

Istilah manajemen berasal dari bahasa Inggris management. Istilah ini ter-bentuk dari akar kata manus, tangan, yang berkaitan dengan kata menagerie yang berarti beternak dalam kegiatan mengendalikan sekumpulan binatang liar. Dalam bahasa latin, manajemen disebut mansionaticum yang berarti pengelolaan rumah besar. Dengan demikian dari segi kata, manajemen berarti pengelolaan. Istilah ma-najemen berkembang pesat dalam organisasi bisnis, dan akhir-akhir ini sering digunakan dalam bidang psikologi pengembangan diri dengan istilah manajemen diri (self management).

Secara sederhana manajemen diri dapat diartikan sebagai kemampuan seseorang untuk mengelola, mengendalikan diri segenap potensi yang dimiliki terutama aspek kognitif, sikap, nilai-nilai untuk mencapai kesuksesan dan kebahagi-aan hidup. Untuk mencapai keberhasilan hidup tidaklah mudah, akan tetapi banyak tantangan, hambatan yang harus dihadapi secara proporsional. Karena itu, individu harus mampu mengevaluasi diri secara jujur, kemudian menetapkan tujuan hidup, menentukan strategi atau kiat mencapai tujuan hidup, dan mengevaluasi kinerja untuk melakukan perbaikan dimasa yang akan datang.

Dalam mencapai tujuan, diperlukan kerja keras, kesungguhan dan optima-lisasi potensi yang ada pada diri kita. Penulis merasa perlu menawarkan suatu strategi untuk mencapai kesuksesan melalui usaha, (1) pemberdayaan diri, (2) mengem-bangkan disiplin diri, (3) meningkatkan kinerja, dan (4) mengelola stres. 


\section{B. PEMBERDAYAAN DIRI}

\section{Konsep Pemberdayaan}

Pemberdayaan, akan lebih mudah dipahami dalam keterkaitannya dengan ketidakberdayaan (powerlessness), yang secara nyata maupun yang dibayangkan, ketidakmampuan untuk menolong diri sendiri (learned helpness), keterasingan, perasaan tidak berdaya menentukan dan mengatur hidupnya sendiri (loss of sense of control over one's own life). Freire (1999) mengemukakan konsep ketidakber-dayaan sebagai akibat individu yang berperan sebagai obyek terhadap lingkungan, dan bukan sebagai subyek yang bertindak di dalam atau terhadap dunia sekitarnya. Peran tersebut berakibat pada individu mengasingkan diri pada keikutsertaan dalam membangun kenyataan-kenyataan sosial. Lebih lanjut Freire, menegaskan bahwa ketidakberdayaan dihasilkan dari penemuan secara pasif dari kebudayaan opresif (oppression) yang given, atau menyerah terhadap suatu kebudayaan diam (culture of silence).

Ketidakberdayaan adalah sebagai salah satu bentuk interaksi antara indivi-du dengan lingkungannya dan merupakan kombinasi dari sikap menyalahkan diri sendiri, perasaan terasing dari sumber-sumber pengaruh sosial, pengalaman tidak memiliki akses atau suara dalam menentukan suatu keadaan, secara ekonomis ren-tan atau juga perasaan tidak memiliki harapan. (Rappaport \& Hess, 1994). Pem-berdayaan itu berkaitan erat dengan perasaan-perasaan individu, harga diri dan kepercayaan diri. Pemberdayaan juga tidak dapat dipisahkan keterkaitannya dengan aspek sosial, ekonomi, politik di lingkungan individu yang bersangkutan.

Pemberdayaan sebagai proses pemberian kekuatan atau daya yang bertu-juan membangkitkan kesadaran, pengertian dan kepekaan individu terhadap perkembangan sosial, ekonomi, dan politik sehingga ia memiliki kemampuan untuk memperbaiki dan meningkatkan kedudukannya (Kindervater (1989). Pemberdayaan dalam pengertian di atas sebagai usaha dari luar individu/kelompok orang untuk meningkatkan kemampuan atau daya agar individu atau kelompok orang peka terhadap perubahan lingkungan yang terjadi dan mampu menyesuaikan pe-rubahan yang terjadi. Pemberdayaan diri berarti proses peningkatan kemampuan atau daya yang dilakukan oleh individu yang bersangkutan dengan tujuan untuk meningkatkan kepekaan terhadap perubahan dan perkembangan lingkungan yang terjadi sehingga berkemampuan untuk mengevaluasi diri dan meningkatkan status sosialnya. 


\section{Proses Pemberdayaan Diri}

Proses pemberdayaan biasanya dilaksanakan dengan dua cara, yaitu secara konseptual dan empirik (Freire, 1999). Pemberdayaan secara konseptual berarti pe-ningkatan kemampuan menciptakan ide/gagasan atau secara lebih spesifik proses penyadaran diri (self awareness). Selanjutnya pemberdayaan empirik yang dilaku-kan individu untuk memperbaiki kehidupan dengan cara yang praktis. Sedangkan Stewart (1994), mengemukakan langkah-langkah pemberdayaan diri meliputi (1) memeriksa keterbatasan diri, (2) memperluas batas, (3) membangun dialog batin yang positif, (4) mengupayakan dukungan.

Melihat keterbatasan diri, berarti seseorang melakukan evaluasi diri ter-hadap kelebihan dan kekurangan yang melekat pada dirinya. Sebagai anggota or-ganisasi atau karyawan membandingkan standar kinerja yang ditetapkan dengan kinerja yang ditampilkan (kinerja yang telah dicapai). Namun tidak jarang pemba-tasan dilakukan oleh institusi terutama dalam mengambil inisiatif dan kebijakan. Memperluas batas, karyawan dapat melakukan pekerjaan melebihi standar yang ditetapkan berarti berhasil memperluas batas (standar kinerja). Faktor pimpinan melakukan intervensi terhadap karir seseorang. Membangun dialog batin yang positif, merupakan dialog internal, yaitu mengirim pesan pada diri sendiri, bicara dengan diri sendiri walaupun tidak menggunakan kata-kata. Pesan tentang situasi atau keinginan kita terhadap orang lain. Dialog batin yang negatif menghalangi pemberdayaan diri. Mengupayakan dukungan, lingkungan kerja dapat dimanfa-atkan untuk memberdayakan diri (self empowering), teman kerja, customer, atau sarana dan prasaran organisasi.

Dalam kalimat yang berbeda, Prijosaksono \& Sambel (2003: 57) menggu-nakan istilah memaksimalkan kemampuan pribadi untuk pengertian pemberdaya-an diri. Dikatakannya, usaha memaksimalkan pribadi melalui proses sebagai be-rikut: (1) menggunakan kekuatan pikiran, (2) menetapkan tujuan, (3) menjadi kre-atif dan produktif, (4) persimpangan karir, (5) membangun reputasi.

Menggunakan kekuatan pikiran, salah satu upaya untuk memaksimalkan potensi dan kekuatan yang kita miliki adalah pada kekuatan pikiran kita. Pikiran anda menentukan kesusksesan anda, dan kebiasaan anda menentukan masa depan anda. Menguasai dan mengendalikan pikiran kita hanya dapat dilakukan melalui serangkaian latihan terus menerus dan disiplin diri yang kuat. Melalui serangkaian latihan untuk mengoptimalkan kekuatan pikiran kita bisa memanfaatkan kekuatan dahsyat dari pikiran kita secara otomatis. Menetapkan tujuan, 
berarti menentu-kan tujuan yang anda lihat dalam perspektif kehidupan anda mulai saat ini dan dimulai dari apa yang anda miliki saat ini. Jangan melihat kebelakang maupun menyesali apa yang ingin anda miliki saat ini. Menjadi kreatif dan produktif, kreativitas adalah kemampuan untuk mencipta, termasuk menciptakan realitas baru dalam kehidupan kita. Produktif berarti mampu menghasilkan sesuatu secara terus menerus. Persimpangan karir, diantara kita mungkin sedang berada dipersimpangan karier, apakah bekerja sebagai profesional ataukah memulai bisnis sendiri, terutama usia sekitar 40 tahun "life begins at fourty". Pilihan apapun yang kita am-bil akan menentukan masa depan kita. Membangun reputasi, atau dalam istilah Inggris disebut "personal brand development". Membangun reputasi berarti mem-bangun persepsi orang lain tentang diri kita. Persepsi orang terhadap kita bisa po-sitif atau negatif bergantung dari pengalaman dan interaksi orang lain dengan kita. Reputasi seseorang dapat dikenali dari gagasan, kecerdasan, kemampuan, pemikiran dan pandangan-pandanganya terhadap dunia sekitarnya.

\section{MENGEMBANGKAN DISIPLIN DIRI}

\section{Hakekat Disiplin}

Istilah disiplin berasal dari kata latin "Discipulus" yang berarti "student" atau "pupil" (Mc Phail, 1982). Pengertian lain adalah "disciple" yang berarti se-orang yang menerima instruksi dari yang lain, khususnya seseorang yang menerima doktrin dari gurunya yang menbantu perkembangannya, atau diartikan juga sebagai pengikut (follower).

Sutisna (1993) membedakan disiplin menjadi dua kategori yaitu, disiplin positif dan disiplin negatif. Disiplin positif adalah proses atau hasil pengembangan karakter, pengendalian diri, keadaan teratur dan efisiensi. Sedangkan disiplin ne-gatif adalah penggunaan hukuman atau ancaman hukuman untuk membuat orang-orang mematuhi perintah dan mengikuti peraturan dan hukum. Konsep disiplin itu merujuk kepada peraturan, norma, atau batasan-batasan tingkah laku dengan pena-naman disiplin, individu diharapkan dapat berperilaku yang sesuai dengan norma tersebut sebagaimana dikemukakan oleh Crow dan Crow (1980:274) sebagai berikut:

"Implicit in the concept of discipline are (1) the presence of rules, regulations, standard, or other conduct the determiners, and (2) the control of impulsive overt expressions of personal the desire, interest, or ambition 
in accordance with appropriate and accep-table societal standards.

Pengertian di atas mengisaratkan bahwa dalam pelaksanaan disiplin itu senantiasa merujuk kepada peraturan atau patokan-patokan yang menjadi unsur pe-nentu tingkah laku, disamping itu adanya unsur pengontrolan terhadap tingkah la-ku supaya sesuai dengan patokanpatokan yang berlaku atau diterima masyarakat.

Disiplin merupakan salah satu cara untuk mengadakan perubahan tingkah laku dengan pihak perorangan atau kelompok. Hal itu dijalankan atas otoritas atau wewenang. Situasi disiplin timbul pada saat seseorang atau kelompok telah melanggar norma-norma tingkah laku yang berlaku dalam kelompok atau organisasi.

Dari beberapa pendapat mengenai disiplin dapat disimpulkan bahwa disiplin adalah suatu kondisi yang tercipta dan terbentuk melalui proses dari serangkaian perilaku yang menunjukkan ketaatan, kepatuhan, kesetiaan, keteraturan dan ketertiban terhadap suatu ketentuan atau aturan yang telah disepakati dan ditetapkan terlebih dahulu.

\section{Disiplin Diri}

Membangun disiplin tidak mudah, akan tetapi perlu latihan secara tekun un-tuk melakukan kegiatan tepat waktu, tidak menunda pekerjaan, dan menyelesai-kan pekerjaan secara konsisten. Ravianto (1985) mengemukakan sebagai berikut: “. . . disiplin merupakan sikap kejiwaan seseorang atau kelompok yang senantiasa berkehendak untuk mengikuti atau mematuhi keputusan yang telah ditetapkan". Baik disiplin diri maupun disiplin kerja kedua-duanya mempunyai pengaruh ter-hadap prestasi kerja yang ditampilkan.

Sebagaimana telah dijelaskan dalam pengertian disiplin di atas, maka pen-dekatan disiplin positif dapat menumbuhkan kesadaran bagi individu untuk mengerjakan tugas karena tidak dibayangi rasa takut terhadap ancaman hukuman. Dijelaskan oleh Sutisna (1993) bahwa pendekatan disiplin positif dapat menumbuhkan sikap dan suasana yang kondusif bagi seseorang, mereka melakukan kegiatan ber-dasarkan kesadaran sendiri bukan karena paksaan. Lebih lanjut dikemukakan oleh Sutisna (1993) bahwa perilaku disiplin meliputi (1) kehadiran kerja tepat waktu, (2) kerjasama yang baik dengan atasan dan rekan kerja, (3) sopan santun dengan dengan semua anggota organisasi, dan (4) konsisten dalam bekerja. 
Seseorang yang memiliki disiplin diri tidak hanya mampu mentaati pera-turan organisasi, akan tetapi juga mampu untuk mengatur dirinya, atau mengarah-kan diri untuk mencapai tujuan yang diharapkan. Dikemukakan oleh Chaplin (1989) bahwa yang berdisiplin diri itu mampu mengatur tingkah lakunya sendiri, dan mem-punyai tanggung jawab untuk merencanakan kegiatannya sendiri. Kemampuan meng-atur diri mengandung arti bahwa individu mampu memilah-milah perilakunya. Setiap perilaku dipertimbangkan atas dasar baik buruknya, manfaat dan mudharatnya, baik bagi dirinya maupun bagi orang lain. Sedangkan untuk merencanakan kegiatannya sendiri, individu tersebut mampu mengarahkan perilaku atau aktivitasnya dalam mencapai tujuan yang diharapkan.

Dari beberapa pendapat tentang disiplin, dapat disimpulkan bahwa disiplin diri itu merupakan kemampuan mengatur diri dan mentaati peraturan atau norma yang berlaku atas kesadaran sendiri. Perilaku yang terungkap di atas merupakan gambaran atau perwujudan pribadi yang bertanggung jawab.

\section{MENINGKATKAN KINERJA}

\section{Konsep Kinerja}

Masalah kinerja selalu menjadi perhatian dalam manajemen karena berka-itan dengan produktivitas organisasi. Dengan kata lain, kinerja individu mempe-ngaruhi produktivitas organisasi secara keseluruhan.

Performansi (kinerja) diartikan sebagai ungkapan kemampuan yang dida-sari oleh pengetahuan, sikap dan keterampilan dan motivasi dalam menghasilkan sesuatu (Fatah, 1996: 13). Karakteristik kinerja dimaksud adalah melaksanakan tugas sesuai dengan program yang ditetapkan, memiliki motivasi dan kemampuan kerja yang tinggi, serta berhasil mencapai tujuan organisasi. Kinerja juga mempunyai makna sebagai unsur perilaku yang ditampilkan seseorang sehubungan dengan pekerjaan. Secara matematika (mathematically), performansi kerja (job per-formance) adalah fungsi perkalian kemampuan (ability) dengan motivasi (moti-vation), (McAfee \& Poffenberger, 1992: 3). Lebih lanjut dijelaskannya: "Ability refers to the employee,s prior training, experience, and education, whereas moti-vation is typically thought of as an employee,s desire to perform a job well". Ke-mampuan mengacu pada pelatihan, pengalaman, dan pendidikan yang diperoleh karyawan, sedangkan motivasi adalah keinginan untuk melaksanakan suatu pekerjaan 
dengan baik. Dengan perkataan lain, motivasi kerja yang tinggi disertai dengan kemampuan melaksanakan tugas dapat meningkatkan kinerja individu dan organisasi. Kinerja biasanya dilatar belakangi oleh pengetahuan, keterampilan, proses dan nilai-nilai yang ada pada sipelaku untuk membuat keputusan secara individual untuk melakukan sesuatu dalam hubungannya dengan tujuan yang akan dicapai. Dengan demikian kinerja merupakan keseluruhan perilaku dan kemampuan dari seseorang yang ditampilkan dalam kaitannya dengan pekerjaan.

Gibson, Invancevich, \& Donnelly, (1996) mengartikan kinerja adalah pe-rilaku yang ditunjukkan oleh individu dalam mengerjakan suatu tugas yang dibe-bankan. Kinerja selalu dikaitkan dengan individu atau kelompok individu dalam melaksanakan pekerjaan di dalam organisasi. Hal ini didasari pemikiran bahwa kinerja individu berpengaruh terhadap kinerja organisasi. Secara lebih detail, Smith (1982), menjelaskan bahwa kinerja berhubungan dengan tiga aspek pokok yaitu: perilaku, hasil, dan efektivitas organisasi. Aspek perilaku menunjuk pada usaha-usaha yang dilakukan dalam upaya mencapai tujuan tertentu, dan perilaku individu memberikan hasil terhadap kerja. Hasilnya bisa obyektif dan bisa subyektif. Aspek hasil menunjuk pada efektivitas perilaku, sedangkan efektivitas organisasi menunjuk pada hasil kerja organisasi yang menekankan pada proses. Dari aspek psikologis, kinerja dapat dikatakan sebagai tingkah laku kerja seseorang yang pada akhirnya menghasilkan sesuatu yang menjadi tujuan dari pekerjaannya. Karena itu untuk menganalisis kinerja seseorang dapat dilakukan dengan cara mempelajari ka-rakteristik perilaku kerja yang diperlihatkan. Karakteristik dimaksud antara lain; mempunyai semangat tinggi, kemampuan membangun hubungan kerjasama de-ngan atasan, rekan kerja, dapat mengatasi masalah yang berkaitan dengan tugas-tugas yang dibebankan.

Kinerja berkaitan erat dengan peningkatan kualitas kerja, sebagaimana di-kemukakan oleh Zamroni (2003: 120) sebagai berikut; “. . .dalam meningkatkan kualitas kerja harus menyentuh tiga aspek yaitu, kemampuan, semangat, dan de-dikasi". Kemampuan akan dapat meningkat manakala karyawan berada pada iklim kerja yang kondusif sehingga muncul inisiatif dan kreativitas kerja. Semangat kerja berkaitan dengan dorongan jiwa seseorang untuk bekerja lebih giat dan produk-tif. Sedangkan dedikasi sebagai wujud pengorbanan tenaga, pikiran, dan waktu demi keberhasilan organisasi. 


\section{Strategi Meningkatkan Kinerja}

Kinerja individu dapat dioptimalkan melalui berbagai cara, antara lain, (1) belajar, (2) pelatihan, (3) menulis, (4) komunikasi yang efektif, (5) membangun jaringan, (6) memotivasi diri.

Salah satu komponen penting untuk memaksimalkan potensi diri adalah belajar, belajar memungkinkan kita mengembangkan wawasan (kognitif), sikap serta nilai-nilai pribadi secara terus menerus. Belajar dapat menjaga eksistensi manusia untuk senantiasa menjaga kelangsungan hidupnya dengan mengikuti perkem-bangan lingkungan. Pelatihan membekali keterampilan (vocational skill) seseorang, berarti meningkatkan kemampuan teknis yang dapat dimanfaatkan untuk me-ngisi permintaan tenaga kerja terampil. Menulis merupakan salah satu cara seseo-rang agar gagasan, pemikiran, pandangan hidup, kemampuan, dan kecerdasannya dapat dikenali dan dimanfaatkan oleh orang lain, organisasi, bahkan masyarakat luas. Terdapat banyak cara yang dapat ditempuh, diantaranya menulis buku dan/ atau artikel di media masa atau membuat situs web di internet untuk mengekspre-sikan gagasan kita. Komunikasi yang efektif, komunikasi dapat diartikan sebagai proses penyampaian gagasan dari seseorang kepada orang lain. Sedangkan tujuan komunikasi adalah agar pesan yang disampaikan oleh komunikator dapat dipahami oleh komunikan sesuai maksud pengirim pesan. Komunikasi efektif apabila berlangsung dua arah, tidak terlihat lagi peran komuniktor dan komunikan, kedu-anya berganti posisi. Membangun jaringan, untuk meningkatkan nilai dan kuali-tas kehidupan, kita memerlukan teman, relasi, kolega, mitra atau orang-orang yang dapat mendukung kita, baik dalam pengembangan kehidupan pribadi maupun pro-fesional kita. Sesungguhnya, semakin jauh kita maju dalam perjalanan sukses, kita semakin menyadari bahwa yang membuat kita sukses bukanlah uang, gagasan, atau antusiasme semata, melainkan karena orang lian. Memotivasi diri, motivasi sebagai suatu keadaan di dalam diri seseorang (inner state) yang mendorong, mengaktifkan, atau menggerakkan dan yang mengarahkan atau menyalurkan perilaku ke arah tujuan. Dengan demikian, motivasi dipandang sebagai tenaga pendorong kegiatan seseorang, sedangkan faktor pendorong aktivitas seseorang dapat berasal dari dalam dan dari luar. Motivasi yang berasal dari dalam diri seseorang disebut mo-tivasi internal. Sedangkan motivasi yang datangnya dari luar diri seseorang disebut motivasi eksternal, yaitu tenaga pendorong yang datang dari orang lain; pimpinan, rekan sekerja, atau orang di luar tempat kerja. setiap proses motivasi dan perilaku akan menghasilkan berbagai peristiwa yang bervariasi antara 
individu satu dengan lainnya, ataupun pada setiap individu dalam waktu dan tempat berbeda. Motivasi yang berasal dari diri sendiri mempunyai kekuatan pendorong yang lebih besar dan bertahan lebih lama dibandingkan motivasi eksternal.

\section{E. PENUTUP}

Ketidakberdayaan adalah sebagai salah satu bentuk interaksi antara individu dengan lingkungannya dan merupakan kombinasi dari sikap menyalahkan diri sendiri, perasaan terasing dari sumber-sumber pengaruh sosial, pengalaman tidak memiliki akses atau suara dalam menentukan suatu keadaan, secara ekonomis rentan atau juga perasaan tidak memiliki harapan. (Rappaport \& Hess, 1994). Pemberdayaan itu berkaitan erat dengan perasaan-perasaan individu, harga diri dan kepercayaan diri. Pemberdayaan juga tidak dapat dipisahkan keterkaitannya dengan aspek sosial, ekonomi, politik di lingkungan individu yang bersangkutan.

Pemberdayaan sebagai proses pemberian kekuatan atau daya yang bertu-juan membangkitkan kesadaran, pengertian dan kepekaan individu terhadap per-kembangan sosial, ekonomi, dan politik sehingga ia memiliki kemampuan untuk memperbaiki dan meningkatkan kedudukannya (Kindervater (1989). Pemberdayaan dalam pengertian di atas sebagai usaha dari luar individu/kelompok orang untuk meningkatkan kemampuan atau daya agar individu atau kelompok orang peka terhadap perubahan lingkungan yang terjadi dan mampu menyesuaikan perubahan yang terjadi. Pemberdayaan diri berarti proses peningkatan kemampuan atau daya yang dilakukan oleh individu yang bersangkutan dengan tujuan untuk meningkatkan kepekaan terhadap perubahan dan perkembangan lingkungan yang terjadi sehingga berkemampuan untuk mengevaluasi diri dan meningkatkan status sosialnya.

\section{REFERENSI}

Chaplin, J.P. (1989). Dictionary of Psychology. New York: Dell Publishing Co.

Crow, L.D. dan Crow, A. (1980). Introduction to Education Fundamental Princ-iples and Modern Practice. New York: American Book Company. 
Fatah, N. (1996). Landasan Manajemen Pendidikan. Bandung: Remaja Rosda- karya.

Freire, P. (1990). Politik Pendidikan: Kebudayaan, Kekuasaan, dan Pembebasan. Yogyakarta: Pustaka Pelajar.

Gibson, J.L., Invancevich, J.M. dan Donnelly, Jr. J.H. (1996). Organisasi: Perilaku, struktur dan proses. (edisi kedelapan), Alih Bahasa: Nunuk Ardiani, Jakarta: Binarupa Aksara.

Kindervatter, S. (1989). Nonformal Education as An Empowering Process: Massachusetts: Center for International Education University of Massachusetts.

McAfee, R.B. \& Poffenberger, W. (1992). Productivity Strategies. Englewood Cliffs, New Jersey: Prentice-Hall, Inc

McPhail, P. (1982). Social and Moral Education. London: Prentice-Hall International, Inc.

Prijosaksono, A. (2002). Self Management Series: Instead of Wondering "who moved my cheese") Create Your Own Cheese. (8 langkah kreatif mengen-dalikan perubahan dalam kehidupan anda). Jakarta: Elex Media Komputindo.

Prijosaksono, A. \& Sembel, R. (2003). Self Management Series: If YouWant to Be Rich an Happy Maximize Your Strengt (Kiat-kiat Meningkatkan dan Me-maksimalkan Kinerja). Jakarta: Elex Media Komputindo.

Ravianto (1985). Produktivitas dan Teknologi. Jakarta: Lembaga Sarana Informasi Usaha dan Produktivitas.

Smith. (1982). Management System Analysis and Aplication. New Jersey: Prentice Hall, Inc.

Sutisna, O (1993). Administrasi Pendidikan: Dasar Teoretis untuk Praktek Profe-sional. Bandung: Angkasa

Zamroni. (2003). Paradigma Pendidikan Masa depan. Jakarta: Bigraf

Publishing. 